\title{
Sistem Pendukung Keputusan Pemilihan Sekolah Anak Dengan Menggunakan Metode Analytical Hierarchy Process (AHP) Dan Metode Perbandingan Eksponensial (MPE)
}

\author{
Armiyana $^{1}$, Reski Mai Candra ${ }^{2}$ \\ ${ }^{1,2}$ Teknik Informatika UIN Sultan Syarif Kasim Riau \\ Jl. H.R. Soebrantas no. 155 KM. 18 Simpang Baru, Pekanbaru 28293 \\ armiyana17@gmail.com ${ }^{1}$, reski.candra@uin-suska.ac.id ${ }^{2}$
}

\begin{abstract}
Abstrak - Penentuan sekolah sangat penting bagi orangtua untuk memperoleh pendidikan yang layak. Pemilihan sekolah merupakan masalah utama bagi orangtua disimpulkan dari hasil beberapa pertanyaan kepada orangtua, karena banyaknya kriteria penentu yang dipertimbangkan maka dari penulis berinisiatif untuk mengembangkan sistem tentang pemilihan sekolah. Banyaknya pilihan sekolah yang masing-masing memiliki kelebihan dan kekurangan serta kurang objektifnya data hasil analisa sehingga perlu dievaluasi berulangulang. Untuk itu perlu sistem yang mampu mengatasi hal tersebut. Sistem yang dirancang yaitu sistem pendukung keputusan untuk pemilihan sekolah menggunakan metode Analytical Hierarchy Process (AHP) dan metode Perbandingan Eksponensial (MPE). Sistem ini telah berhasil memberikan solusi dan informasi untuk pemilihan sekolah. Pengujian di lakukan menggunakan user acceptance, di peroleh tingkat akurasi sistem $80 \%$ kurang akurasi $20 \%$ dapat disimpulkan bahwa sistem ini lebih objektif dan menghemat waktu dalam pemilihan sekolah yang terkomputerisasi.
\end{abstract}

Kata kunci - AHP, MPE, Sekolah, Sistem Pendukung Keputusan

\section{PENDAHULUAN}

SPK (sistem pendukung keputusan) adalah sistem yang dibangun untuk menyelesaikan berbagai masalah yang bersifat manajerial atau organisasi perusahaan yang dirancang untuk mengembangkan efektivitas dan produktivitas para manajer untuk menyelesaikan masalah dengan bantuan teknologi komputer. Hal lainnya yang perlu dipahami adalah bahwa SPK bukan untuk menggantikan tugas manajer akan tetapi hanya sebagai bahan pertimbangan bagi manajer untuk menentukan keputusan akhir.

Pada dasarnya SPK merupakan pengembangan lebih lanjut dari Sistem Informasi Manajemen terkomputerisasi yang dirancang sedemikian rupa sehingga bersifat interaktif dengan pemakainya. Interaktif dengan tujuan untuk memudahkan integrasi antara berbagai komponen dalam proses pengambilan keputusan seperti prosedur, kebijakan, analisis, pengalaman dan wawasan manajer untuk mengambil keputusan yangn lebih baik.

Dalam menentukan suatu keputusan banyak faktor yang mempengaruhi pengambilan keputusan seorang pengambil keputusan, sehingga dipandang perlu untuk mengidentifikasi berbagai faktor yang penting dan mempertimbangkan tingkat pengaruh suatu faktor dengan faktor yang lainnya sebelum mengambil keputusan akhir, oleh karena itu secara spesifik penulis akan membahas salah satu permasalahan pada seleksi penerimaan beasiswa dengan langkah demi langkah dengan menggunakan metode SPK untuk menghasilkan keputusan akhir yang disebut solusi dari suatu masalah.

Definisi formal tentang SPK tidak memberikan fokus yang konsisten karena masingmasing defenisi berusaha mempersempit populasi secara berbeda- beda Turban [4].

Kemudian Little[5], mendefenisikan SPK sebagai "sekumpulan prosedur berbasis model untuk data pemrosesan dan penilaian guna membantu para namajer mengambil keputusan". Dia menyatakan bahwa untuk sukses, sistem tersebut haruslah sederhana, cepat, mudah dikontrol, adaftif, lengkap dengan isu-isu penting, dan mudah berkomunikasi.

\section{SISTEM PENDUKUNG KEUTUSAN}

SPK (sistem pendukung keputusan) adalah sistem yang dibangun untuk menyelesaikan berbagai masalah yang bersifat manajerial atau organisasi perusahaan yang dirancang untuk mengembangkan efektivitas dan produktivitas para manajer untuk menyelesaikan masalah dengan bantuan teknologi komputer. Hal lainnya yang perlu dipahami adalah bahwa SPK bukan untuk menggantikan tugas manajer akan tetapi hanya sebagai bahan pertimbangan bagi manajer untuk menentukan keputusan akhir. 
Pada dasarnya SPK merupakan pengembangan lebih lanjut dari Sistem Informasi Manajemen terkomputerisasi yang dirancang sedemikian rupa sehingga bersifat interaktif dengan pemakainya. Interaktif dengan tujuan untuk memudahkan integrasi antara berbagai komponen dalam proses pengambilan keputusan seperti prosedur, kebijakan, analisis, pengalaman dan wawasan manajer untuk mengambil keputusan yangn lebih baik.

Dalam menentukan suatu keputusan banyak faktor yang mempengaruhi pengambilan keputusan seorang pengambil keputusan, sehingga dipandang perlu untuk mengidentifikasi berbagai faktor yang penting dan mempertimbangkan tingkat pengaruh suatu faktor dengan faktor yang lainnya sebelum mengambil keputusan akhir, oleh karena itu secara spesifik penulis akan membahas salah satu permasalahan pada seleksi penerimaan beasiswa dengan langkah demi langkah dengan menggunakan metode SPK untuk menghasilkan keputusan akhir yang disebut solusi dari suatu masalah.

Definisi formal tentang SPK tidak memberikan fokus yang konsisten karena masingmasing defenisi berusaha mempersempit populasi secara berbeda- beda Turban [4].

Kemudian Little[5], mendefenisikan SPK sebagai "sekumpulan prosedur berbasis model untuk data pemrosesan dan penilaian guna membantu para namajer mengambil keputusan". Dia menyatakan bahwa untuk sukses, sistem tersebut haruslah sederhana, cepat, mudah dikontrol, adaftif, lengkap dengan isu-isu penting, dan mudah berkomunikasi.

\section{ANALITYCAL HIERARCHY PROCESS}

Metode AHP dikembangkan oleh Thomas L. Saaty sekitar tahun 1970, Metode ini adalah sebuah kerangka untuk mengambil keputusan dengan efektif atas persoalan yang kompleks.Tiga prinsip memecahkan persoalan dengan AHP, yaitu prinsip menyusun hirarki, prinsip menentukan prioritas, dan prinsip mengukur konsistensi. Proses pengambilan keputusan pada dasarnya memilih suatu alternatif. Peralatan utama AHP adalah sebuah hirarki fungsional dengan input utamanya persepsi manusia. Dengan hirarki, suatu masalah kompleks dan tidak terstruktur dipecahkan ke dalam kelompok- kelompok. Kemudian kelompokkelompok tersebut diatur.

\section{METODE PERBANDINGAN EKPONENSIAL}

Metode Perbandingan Eksponensial (MPE) merupakan salah satu metode untuk menentukan urutan prioritas alternatif keputusan dengan kriteria majemuk. Teknik ini digunakan sebagai pembantu bagi individu pengambil keputusan untuk menggunakan rancang bangun model yang telah terdefinisi dengan baik pada tahapan proses.

Menurut Marimin [6], formulasi perhitungan skor untuk setiap alternative dalam metode perbandingan eksponensial adalah sebagai berikut:

$$
\text { Total Nilai TN } i=\sum_{j=1}^{m}\left(R K_{i j}\right) B_{j}
$$

Dengan:

$\begin{array}{ll}\text { TNi } & \text { Total nilai alternatif ke-i } \\ \text { RKij } & : \text { Derajat kepentingan relative } \\ & \text { kriteria ke-j pada pilihan } \\ & \text { keputusan } \\ \text { TKKj } & : \text { Derajat kepentingan kriteria } \\ & \text { keputusan ke-j; TKKj>0; bulat } \\ \mathrm{n} & : \text { Jumlah pilihan keputusan } \\ \mathrm{m} & : \text { Jumlah kriteria keputusan } \\ \mathrm{j} & : 1,2,3, \ldots . \mathrm{m} ; \\ \mathrm{i} & : 1,2,3, \ldots . \mathrm{n} ;\end{array}$

Metode perbandingan eksponensial merupakan salah satu metode yang digunakan untuk pengambilan keputusan dari beberapa alternatif keputusan dengan kriteria majemuk. Metode ini dikembangkan dengan cara merubah penilaian kualitatif yang berasal dari subyektifitas dari pengambil keputusan menjadi nilai kuantitatif.

\section{ANALISA}

Data yang di gunakan dalam penelitian ini terdiri dari beberapa sumber data, yaitu dari hasil penyebaran angket kepada orangtua wali murid sebanyak 45.

Berikut penjelasannya:

1. = Sangat Tidak Setuju(STS)

2. = Tidak Setuju(TS)

3. = Ragu-Ragu(RR)

4. $=\operatorname{Setuju}(\mathrm{S})$

5. = Sangat Setuju(SS)

Tabel 1. Hasil Kuesioner

\begin{tabular}{|l|l|c|c|c|c|c|}
\hline \multirow{2}{*}{ NO } & \multirow{2}{*}{ KRITERIA } & \multicolumn{5}{|c|}{ Hasil Persen Tingkat Kepentingan } \\
\cline { 3 - 7 } & & STS & TS & RR & S & SS \\
\hline 1 & Jarak & $0 \%$ & $0 \%$ & $0 \%$ & $0.33 \%$ & $0.67 \%$ \\
\hline 2 & Rayon & $0.5 \%$ & $0 \%$ & $0 \%$ & $0.60 \%$ & $0.33 \%$ \\
\hline 3 & Biaya & $0 \%$ & $0.5 \%$ & $0 \%$ & $0.20 \%$ & $0.75 \%$ \\
\hline 4 & Lokasi & $0 \%$ & $0.10 \%$ & $0.4 \%$ & $0.30 \%$ & $0.5 \%$ \\
\hline 5 & Akreditasi & $0 \%$ & $0 \%$ & $0 \%$ & $0.20 \%$ & $0.80 \%$ \\
\hline 6 & Fasilitas & $0 \%$ & $0 \%$ & $0 \%$ & $0.19 \%$ & $0.81 \%$ \\
\hline
\end{tabular}




\begin{tabular}{|l|l|l|l|l|l|l|}
\hline 7 & Lingkungan & $0 \%$ & $0.3 \%$ & $0.4 \%$ & $0.16 \%$ & $0.72 \%$ \\
\hline 8 & $\begin{array}{l}\text { Syarat } \\
\text { Masuk } \\
\text { Sekolah }\end{array}$ & $0.3 \%$ & $0.5 \%$ & $0 \%$ & $0.14 \%$ & $0.78 \%$ \\
\hline 9 & Prestasi & $0.4 \%$ & $0.12 \%$ & $0.2 \%$ & $0.11 \%$ & $0.72 \%$ \\
\hline 10 & kedisiplinan & $0.6 \%$ & $0.11 \%$ & $0.2 \%$ & $0.8 \%$ & $0.73 \%$ \\
\hline 11 & $\begin{array}{l}\text { Sarana } \\
\text { Angkutan } \\
\text { Umum }\end{array}$ & $0.5 \%$ & $0.20 \%$ & $0 \%$ & $0.3 \%$ & $0.72 \%$ \\
\hline
\end{tabular}

\section{IMPLEMENTASI DAN PENGUJIAN}

Pada penelitian ini pengujian dilakukan terhadap 2 koleksi dokumen uji, seperti dapat dilihat pada tabel 1 dan jumlah kelompok yang ingin dibentuk adalah sejumlah 4 dan 7 kelompok.



Gambar 1 Tampilan Menu USER

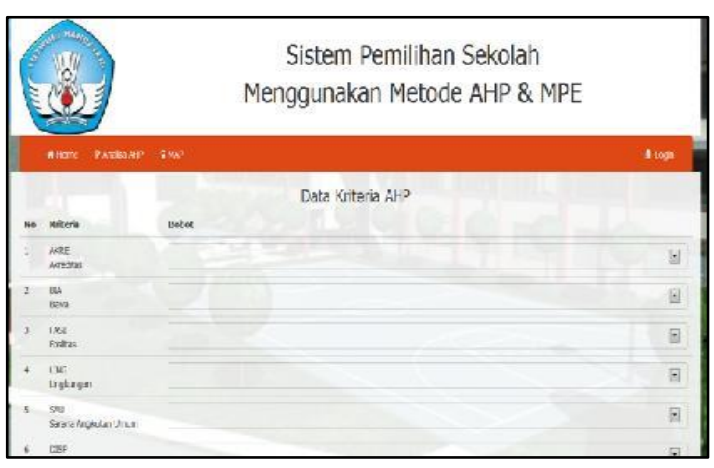

Gambar 2 Tampilan data kriteria AHP



Gambar 3 Tampilan Menu LoginAdmin
Tampilan menu utama akan muncul setelah pengguna sistem melakukan login yang valid. Tampilan menu utama yang dapat diakses Olehadmin adalah menuData Master,Analisadan melihat peta lokasi (Map).

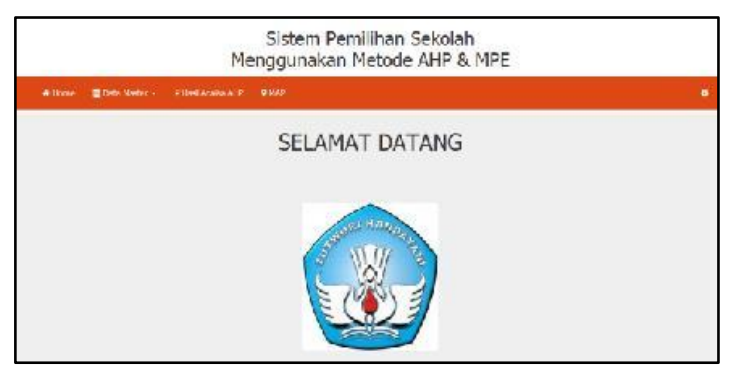

Gambar 4 Tampilan Menu Utama Administrator
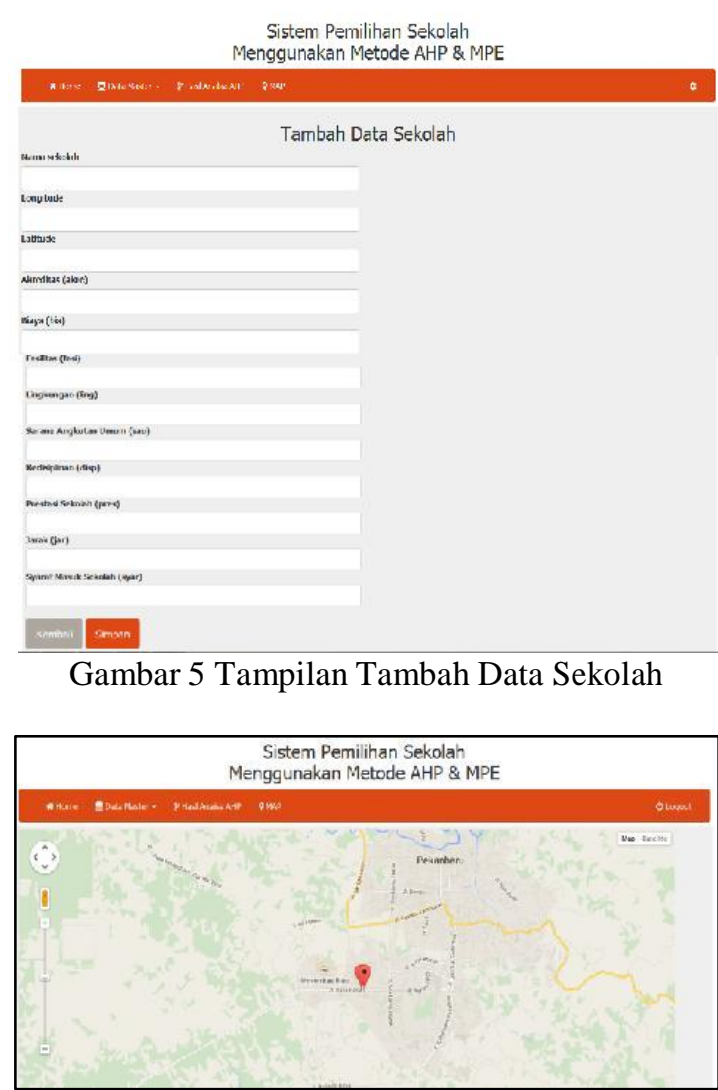

Gambar 6 Tampilan Menu Map

\section{KESIMPULAN}

Setelah melalui tahap pengujian pada sistem pendukung keputusan pemilihan sekolah, maka di dapatkan kesimpulan sebagai berikut:

1. Sistem Pendukung Keputusan ini telah berhasil dibangun dan menghasilkan keputusan berupa perangkingan sekolah terbaik dan layak bagi orang tua menyekelohkan anaknya di tempat yang telah dipilih. 
2. Sistem Pendukung Keputusan ini menerapkan peta yang dapat menampilkan lokasi sekolah.

3. Bobot global hasil keputusan dari perhitungan AHP dan MPE sama dengan bobot global yang dihitung secara manual.

4. Adanya nilai intensitas kepentingan pada setiap kriteria, orangtua hanya memasukkan nilai masing-masing bobot perbandingan berpasangan karena sistem akan memproses secara otomatis sehingga kekonsistensian nilai perbandingan memenuhi syarat $(\mathrm{CR}<0,1)$ terjamin.

5. Data kriteria bersifat statis, dimana nilai bobot kriteria diinputkan langsung ke dalam database.

\section{REFERENSI}

[1] Amri, "Negara Sangat Mendukung Setiap Warga Negaranya Untuk Meraih Pendidikan setinggi- tingginya" 2011

[2] faturrahma, "Sistem Pengembilan Keputusan Menggunakan Metode Analytical Hierarchy Process (AHP) Dalam Memilih Sekolah Menengah Pertama (SMP) dengan Menggunakan Metode Analytical Hierarchy Process (AHP)"2011.

[3] Ferry Jumardi M "Metode Perbandingan Eksponensial Dalam Menenrukan Calon Pejabat Kepala Biro" 2011.

[4] Turban, Efraim dan E.Aronson, Jay dan Liang, Peng, Ting. 2005. "Decision Support System and Intelligent System". Penerbit Andi : Yogyakarta

[5] Little, mendefenisikan SPK sebagai "Sekumpulan Prosedur Berbasis Model Untuk Data Pemrosesan Dan Penilaian Guna Membantu Para Namajer Mengambil Keputusan"

[6] Suryadi, Kadarsah, dan Ramdhani, M.Ali, "Sistem Pendukung Keputusan Suatu Wacana Struktural Idealisasi dan Implementasi Konsep Pengambilan Keputusan" Bandung: PT. Remaja Rosdakarya, Edisi Kedua, 2000

[7] Hermawan, Julius. Membangun Decision Support System. Penerbit Andi : Yogyakarta 2005

[8] Irsal Ismed, ”Rancang Bangun Sistem Informasi Penilaian Training Menggunakan Metode Perbandingan Eksponensial" 2009.

[9] Yuli astuti dan teman-teman "AHP (Analytical Hierarchy Process) Untuk Pemodelan SPK (Sistem Pengambilan Keputusan) Pemilihan Sekolah Tinggi Komputer" 2009. 